\title{
Dental Base
}

National Cancer Institute

\section{Source}

National Cancer Institute. Dental Base. NCI Thesaurus. Code C62564.

Material used on the surfaces of a prepared cavity for protection and insulation of the tooth tissues prior to placement of a restoration. 